\title{
PIONEER
}

VOLUME 12, Issue 2, December 2020: 192 - 203

\section{IMPROVING STUDENTS' SPEAKING ABILITY THROUGH STORY COMPLETION TECHNIQUE IN NARRATIVE TEXT}

\author{
${ }^{1}$ Khoiriyah Shofiyah Tanjung \\ ${ }^{1}$ IAIN Takengon \\ Ishofee_niez@yahoo.co.id \\ ${ }^{2}$ Rahmadhani Fitri \\ ${ }_{2}^{2}$ SMP IT Az-Zahra Takengon \\ ${ }^{2}$ rahmadhanifitri02@gmail.com
}

\begin{abstract}
This research aims to find out how to improve students' speaking ability by using Story Completion Technique. The writers applied Collaborative Classroom Action Research as the method of research, where there are four steps that must be followed, they are: planning, action, observation and reflection. In this research, the writers only conducted one cycle due to the fact that the result of the test has been successful. There are 30 eighth grader students of SMPN 1 Takengon as the sample of this research. The data were taken from observation and students' speaking test in pre-test and post-test, then were analyzed quantitatively. The result of the cycle was described qualitatively. From the results of the research, it was found that using Story Completion Technique in speaking lesson was very enjoyable and it encouraged students to speak more fluently. It can be proven from the result of pretest and posttest, which showed that the posttest score is higher than that of the pre-test (2204 for the pretest and 1640 for the posttest). That means the pre-test score is 54.67 and the post-test score is 73.47 .
\end{abstract}

Keywords: speaking ability, story completion technique, narrative text

\section{INTRODUCTION}

Speaking is one of the English skills that must be mastered by English learners. As claimed by Kosdian (2016) in Rifa'at (2018), “of all four simplex skills (listening, reading, speaking, writing) speaking seems to be the most important because people who know languages are referred to as 'speakers' of that language, as if speaking includes all other types know the language." The English learners' fluency sometimes may be the standard of the quality in learning English, as a result speaking becomes a priority to be mastered by the English learners. However, to speak fluently is not easy due to the sub-skills that adhered it, for instance: pronunciation and vocabulary. According to Bygate (2009) in Safitri, Rafli \& Dewanti (2020), when we speak, we have to not only know the knowledge of vocabulary and grammar but also to produce and adapt them to the circumstances. Bygate, Ur (2012) as stated in Hukom (2019) 
claims that people can be called the speaker of a language when they speak a language as if they included all other kinds of knowing. It means that, to speak fluently, speakers not only need to have a good pronunciation but also sufficient vocabulary.

These complexities are the reasons why students face difficulties mastering speaking ability. As the writers found in the field that students of Junior High School are getting problem in speaking. They feel difficult to say everything in English and many students are not able to even speak in public, but the biggest problem is that they are afraid of making mistakes when speaking English and, therefore, they prefer to remain silent. One of examples of the difficulties faced by students is when teachers ask questions in English. Students cannot answer the questions because they do not have the ability to speak English well. The second reason is the students do not understand what their teachers say.

The problem above may be caused by some factors, either from teacher side or student side. From the teacher side, the problem is caused by the technique applied in teaching speaking. They give more emphasis on form than meaning. They teach speaking but the techniques implemented to teach speaking do not provide the students a sufficient opportunity to practice speaking. The activities are more about some exercises on language structure. Even though that is still controlled by the teachers, that does not resemble a real life communication. It is so unnatural.

Meanwhile, from the student side, the problem may be caused by the intrinsic factors, such as their motivation interest. They are not motivated to learn since they strictly think about the accuracy than fluency. They are afraid of producing sentences to avoid being humiliated by the teacher and the fellow students if they make mistakes in terms of grammar, pronunciation, or choice of words. They prefer keeping silent to practicing the target language.

To overcome this problem, it is needed to have some techniques and strategies to make speaking activity interesting for students. One of the techniques which are recommended in teaching speaking is story completion technique in narrative text. According to Adler and Oppenheim (2015), story completion technique in narrative is an activity when students are asked to complete the narrative story, in which children enact play narratives in response to story beginnings (referred to sometimes as stems). Each story-stem present the student with an emotionally evocative and often conflicting 
relationship-oriented story beginning and invites the student to "take over" at the high point of the story, develop a narrative and provide a resolution. Story stems appear to act as a catalyst that requires the student to complete a story that can reveal the student's subjective attitudes, feelings and emotions. In addition, completing a story rests on the students' ability to organize his feelings into coherent stories, to regulate his emotions, and draw on his scripted inner representation of his world, his unique individual experience as well as his cultural and ethnic background.

Based on the background above, the writers then conduct a research to improve students' speaking skill.

\section{REVIEW OF LITERATURE}

The research about students speaking ability has been done by some researchers, two of them are Wijaya, Sukirlan \& Sudirman (2014) and Ashdaq (2017).

The result of the research which has been done by Wijaya et al. (2014) found that story completion technique has increased students' speaking ability. It can be seen from the (1) mean score of the posttest is 71.57 and the significance of value (2-tailed) is $(\mathrm{p}=0.000, \mathrm{p}<0.05)$; (2) students gave positive response toward story completion technique; and (3) although actually students were able to speak well, they were not confident.

Ashdaq (2017) claims that story completion technique can improve the ability of students in International Class program. Using story completion technique in teaching speaking has made some benefits for students, for instance: (1) Students enjoy the speaking class using story completion technique, (2) students have deep attention in the class, (3) students have high motivation to learn English and, (4) students can speak as long as they want. The research shows that there is an improvement of the students' speaking ability resulting from story completion technique. It can be seen from T-test calculation in cycle I is 2,86 and cycle II is 3,25 ; T-table wih $\mathrm{N}=10$ is 1,182 , pre-test in cycle I is 63,6 and post-test is 67,8 . The mean of pre-test in cycle II is 81,4 and post-test is 85,4 . This indicates that by using story completion technique, the students' speaking ability can be improved. 


\section{METHOD}

This research adopted Collaborative Classroom Action Research which includes four steps: planning, action, observation and reflection (Kemmis and Mc Taggard, 1988, as cited in Burns, 2009). (1) Planning is the step when the teacher arranged learning tools and instruments that would be used in the research. (2) In implementing/action step, the writers conducted some learning steps i.e. stimulation, identification of problems, data collection, data processing, verification, and generalization. (3) Observation step focuses on the implementation of story completion technique. (4) The last, reflection step is an evaluation in which the writers and collaborating teacher discussed learning result that has been done in cycle I. Classroom Action research is a cycle process concept, where the teaching and learning process can be redone for several cycles if the result of research is not satisfactory. The cycle process can be seen in the figure 1. The sample of the research is 30 eight grade students of SMPN 1 Takengon, class VIII-1. The writers gave speaking test as the instrument of the data collection. The teacher recorded students' responses during the test. Pretest and posttest were given in order to see the students' improvement in speaking ability. The Minimum Learning Mastery Standard (KKM) of the speaking ability is 70 . This also becomes the criteria of being successful in this research. The data are analyzed quantitatively and qualitatively. Students' score in pretest and posttest are analyzed quantitatively and cycles are described qualitatively. Classroom Action Research has been adopted in this research.

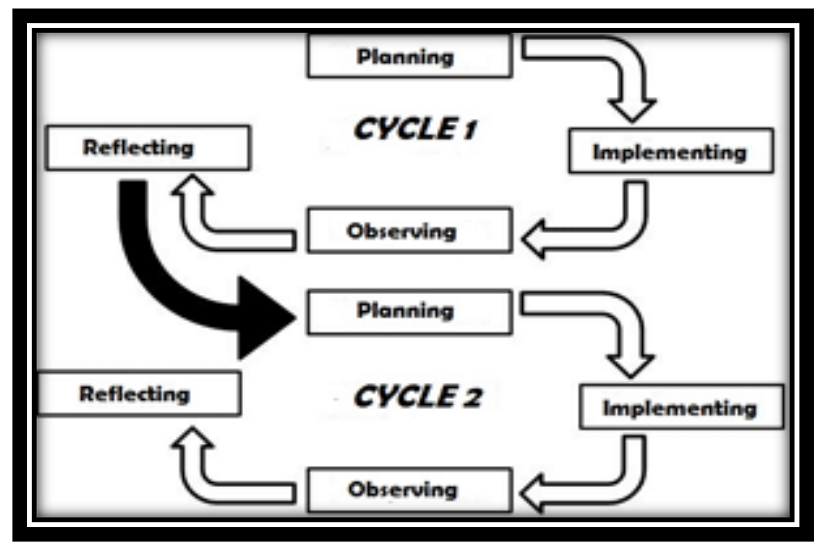

Figure 1. Classroom Action Research's cycle Source: Researchgate.net 


\section{FINDINGS AND DISCUSSION}

\section{Findings}

Based on the cycle that has been applied in this research, it can be concluded that story completion technique is a proper technique in learning speaking. It can be proven from students' response during the teaching and learning process and students' result of test. Story completion technique encouraged students to speak more and they became more enthusiastic to deliver their idea about the story which given by the teacher during the learning process. Students were very vigor to complete the story based on their imagination, in order to hear the full story from their friends. Students did not think about the grammar when they spoke, they also were not afraid of making mistakes. These made students' speaking ability improve.

In implementing the story completion technique, the teacher applied some steps. Firstly, students were divided into several groups. After that, writers gave the story, it was The Mouse Deer and Crocodiles. After that, they were given 15 minutes to understand the story. They could ask about the difficult word. When they understood the story, the writers started the story and they continued the story group by group and group members alternately continued the story. It became an active, creative and interesting English learning. They love to learn the story completion technique because this technique make them more confident.

The improvement of students' speaking ability can be seen from the range of students' speaking test score in preliminary test 1 and 2.

Table 1. Result of Preliminary Test

\begin{tabular}{lcccccc} 
No. Name & \multicolumn{5}{c}{ Categories } \\
\cline { 2 - 6 } & Accent & Grammar & Vocabulary & Fluency & Comprehension & Total \\
& $(30)$ & $(25)$ & $(20)$ & $(5)$ & $(20)$ &
\end{tabular}

\begin{tabular}{cccccccc}
\hline $\mathbf{1}$ & APR & 16 & 15 & 13 & 3 & 13 & 60 \\
\hline $\mathbf{2}$ & AZS & 17 & 15 & 14 & 3 & 14 & 63 \\
\hline $\mathbf{3}$ & AS & 18 & 16 & 15 & 3 & 14 & 66 \\
\hline $\mathbf{4}$ & AKR & 14 & 10 & 13 & 2 & 11 & 50 \\
\hline $\mathbf{5}$ & DM & 16 & 13 & 10 & 3 & 13 & 55 \\
\hline $\mathbf{6}$ & DSA & 15 & 13 & 10 & 2 & 9 & 50 \\
\hline $\mathbf{7}$ & DLV & 17 & 13 & 11 & 3 & 13 & 53 \\
\hline $\mathbf{8}$ & EAP & 15 & 12 & 14 & 2 & 13 & 61 \\
\hline $\mathbf{9}$ & FLL & 18 & 14 & 13 & 3 & & 56 \\
\hline
\end{tabular}




\begin{tabular}{cccccccc}
\hline $\mathbf{1 0}$ & GC & 18 & 14 & 13 & 3 & 13 & 61 \\
\hline $\mathbf{1 1}$ & GS & 15 & 12 & 13 & 3 & 12 & 55 \\
\hline $\mathbf{1 2}$ & GBP & 16 & 12 & 11 & 2 & 11 & 52 \\
\hline $\mathbf{1 3}$ & HZ & 16 & 10 & 10 & 3 & 11 & 50 \\
\hline $\mathbf{1 4}$ & IPM & 18 & 15 & 13 & 2 & 12 & 60 \\
\hline $\mathbf{1 5}$ & IN & 15 & 10 & 11 & 2 & 12 & 50 \\
\hline $\mathbf{1 6}$ & IPS & 16 & 13 & 12 & 3 & 11 & 55 \\
\hline $\mathbf{1 7}$ & IA & 15 & 10 & 12 & 3 & 12 & 52 \\
\hline $\mathbf{1 8}$ & KH & 17 & 14 & 13 & 3 & 12 & 59 \\
\hline $\mathbf{1 9}$ & MW & 15 & 11 & 11 & 3 & 11 & 51 \\
\hline $\mathbf{2 0}$ & MA & 16 & 11 & 12 & 2 & 12 & 53 \\
\hline $\mathbf{2 1}$ & MDR & 14 & 10 & 12 & 2 & 11 & 49 \\
\hline $\mathbf{2 2}$ & NA & 17 & 13 & 13 & 3 & 12 & 58 \\
\hline $\mathbf{2 3}$ & NRM & 15 & 11 & 10 & 3 & 12 & 51 \\
\hline $\mathbf{2 4}$ & NI & 13 & 10 & 12 & 2 & 11 & 48 \\
\hline $\mathbf{2 5}$ & PN & 16 & 12 & 12 & 3 & 11 & 54 \\
\hline $\mathbf{2 6}$ & RS & 15 & 14 & 13 & 2 & 13 & 57 \\
\hline $\mathbf{2 7}$ & RSW & 15 & 10 & 12 & 2 & 11 & 50 \\
\hline $\mathbf{2 8}$ & RN & 16 & 13 & 12 & 2 & 12 & 55 \\
\hline $\mathbf{2 9}$ & SA & 16 & 11 & 10 & 3 & 11 & 51 \\
\hline $\mathbf{3 0}$ & SNA & 15 & 13 & 12 & 2 & 13 & 55 \\
\hline Total & & & & & & $\mathbf{1 6 4 0}$ \\
\hline Average & & & & & $\mathbf{5 4 , 6 7}$ \\
\hline Maximum & & & & & 48 \\
\hline Minimum & & & & & & \\
\hline & & & 12 & & & \\
\hline
\end{tabular}

From the table above, it can be seen that the highest score of students' speaking from 5 categories: accent, grammar, vocabulary, fluency and comprehension is 66 and the lowest is 48 . There is no students who exceeded the Minimum Learning Mastery Standard (KKM) which was 70 . To solve this problem, then the writers implemented story completion technique in teaching speaking, which is called as cycle I.

\section{The result of cycle I}

Planning

In planning step, the writers prepared all things which are needed in story completion technique, for instance: the narrative stores entitled (1) The Tortoise and the Hare and (2) The Monkey and the Crocodile, the lesson plan, the experiment report sheet, and the assessment. 


\section{Action}

Some activities conducted in this step include brainstorming the students before the lesson started. After that, the writers applied story completion technique in narrative text. Narrative text is chosen because the story is very interesting for junior high school students. Story completion technique was done when the teacher (in this case is one of the writers) asked the students to sit down, and then the teacher start to tell the story: (1) The Tortoise and the Hare and (2) The Monkey and the Crocodile. After that the teacher stopped and the student continued the story one by one until three or four sentences. The students can add the new character and new incident from the story. The student also can imagine and make their story by themselves.

\section{Observation}

After implementing the story completion technique in narrative text, the teacher found that students seemed very enthusiastic in completing the story. They were happy to create their own character related to the story told by the teacher. Although there were still pauses and hesitation in completing the story, students are still eager to complete the story.

Based on the result of the observation above, the teacher then conducted the posttest in order to know whether the story completion technique has given effect to students' speaking ability. The result of the posttest can be seen in the table below:

Table 2. The Score of Preliminary test 2

\begin{tabular}{|c|c|c|c|c|c|c|c|}
\hline \multirow[t]{2}{*}{ No. } & \multirow[t]{2}{*}{ Name } & \multicolumn{6}{|c|}{ Categories } \\
\hline & & $\begin{array}{c}\text { Accent } \\
\text { (30) }\end{array}$ & $\begin{array}{c}\text { Grammar } \\
(25)\end{array}$ & $\begin{array}{c}\text { Vocabulary } \\
\text { (20) }\end{array}$ & $\begin{array}{c}\text { Fluency } \\
\text { (5) }\end{array}$ & $\begin{array}{c}\text { Comprehension } \\
\text { (20) }\end{array}$ & Total \\
\hline 1 & APR & 24 & 19 & 16 & 4 & 17 & 80 \\
\hline 2 & AZS & 22 & 18 & 17 & 4 & 16 & 77 \\
\hline 3 & AS & 23 & 20 & 17 & 4 & 17 & 81 \\
\hline 4 & AKR & 21 & 15 & 17 & 3 & 14 & 70 \\
\hline 5 & $\mathrm{DM}$ & 21 & 16 & 15 & 4 & 16 & 72 \\
\hline 6 & DSA & 22 & 15 & 14 & 4 & 15 & 70 \\
\hline 7 & DLV & 21 & 16 & 15 & 4 & 16 & 72 \\
\hline 8 & EAP & 21 & 16 & 16 & 3 & 16 & 72 \\
\hline 9 & FLL & 25 & 18 & 17 & 4 & 18 & 82 \\
\hline 10 & GC & 24 & 19 & 16 & 4 & 17 & 80 \\
\hline
\end{tabular}




\begin{tabular}{cccccccc}
\hline $\mathbf{1 1}$ & GS & 21 & 17 & 17 & 4 & 16 & 75 \\
\hline $\mathbf{1 2}$ & GBP & 22 & 15 & 16 & 3 & 16 & 72 \\
\hline $\mathbf{1 3}$ & HZ & 21 & 16 & 14 & 4 & 16 & 71 \\
\hline $\mathbf{1 4}$ & IPM & 23 & 18 & 16 & 3 & 15 & 75 \\
\hline $\mathbf{1 5}$ & IN & 20 & 17 & 15 & 4 & 16 & 72 \\
\hline $\mathbf{1 6}$ & IPS & 21 & 16 & 14 & 4 & 16 & 71 \\
\hline $\mathbf{1 7}$ & IA & 21 & 16 & 16 & 4 & 16 & 73 \\
\hline $\mathbf{1 8}$ & KH & 24 & 18 & 16 & 4 & 16 & 78 \\
\hline $\mathbf{1 9}$ & MW & 23 & 14 & 16 & 4 & 15 & 72 \\
\hline $\mathbf{2 0}$ & MA & 22 & 15 & 16 & 3 & 15 & 71 \\
\hline $\mathbf{2 1}$ & MDR & 21 & 16 & 15 & 3 & 15 & 70 \\
\hline $\mathbf{2 2}$ & NA & 23 & 15 & 16 & 4 & 16 & 74 \\
\hline $\mathbf{2 3}$ & NRM & 21 & 16 & 16 & 4 & 16 & 73 \\
\hline $\mathbf{2 4}$ & NI & 20 & 16 & 16 & 3 & 15 & 70 \\
\hline $\mathbf{2 5}$ & PN & 23 & 14 & 15 & 4 & 16 & 72 \\
\hline $\mathbf{2 6}$ & RS & 21 & 17 & 16 & 4 & 17 & 75 \\
\hline $\mathbf{2 7}$ & RSW & 22 & 15 & 14 & 4 & 15 & 70 \\
\hline $\mathbf{2 8}$ & RN & 21 & 16 & 15 & 3 & 16 & 71 \\
\hline $\mathbf{2 9}$ & SA & 22 & 14 & 16 & 4 & 16 & 72 \\
\hline $\mathbf{3 0}$ & SNA & 21 & 16 & 15 & 3 & 16 & 71 \\
\hline Total & & & & & & $\mathbf{2 2 0 4}$ \\
\hline Average & & & & & $\mathbf{7 3 , 4 7}$ \\
\hline Maximum & & & & & & 70 \\
\hline Minimum & & & & & & \\
\hline
\end{tabular}

From the table above, it can be concluded that there is an improvement of students' speaking score. The highest score in posttest 82 and the lowest is 70 and it has fulfilled the Minimum Learning Mastery Standard (KKM). The difference of result in pretest and posttest also can be seen in the table below:

Table 3. The deviation of Preliminary test 1 and 2

\begin{tabular}{cccccc}
\hline No & Name & Pre-Test & Post-Test & Deviation $(\mathbf{d})$ & $\begin{array}{c}\text { Squared Deviation } \\
\left(\mathbf{d}^{\mathbf{2}}\right)\end{array}$ \\
\hline $\mathbf{1}$ & APR & 60 & 80 & 20 & 400 \\
\hline $\mathbf{2}$ & AZS & 63 & 77 & 14 & 196 \\
\hline $\mathbf{3}$ & AS & 66 & 81 & 15 & 225 \\
\hline $\mathbf{4}$ & AKR & 50 & 70 & 20 & 400 \\
\hline $\mathbf{5}$ & DM & 55 & 72 & 17 & 289 \\
\hline $\mathbf{6}$ & DSA & 50 & 70 & 20 & 400 \\
\hline
\end{tabular}




\begin{tabular}{|c|c|c|c|c|c|}
\hline 7 & DLV & 53 & 72 & 19 & 361 \\
\hline 8 & EAP & 56 & 72 & 16 & 256 \\
\hline 9 & FLL & 61 & 82 & 21 & 441 \\
\hline 10 & GC & 61 & 80 & 19 & 361 \\
\hline 11 & GS & 55 & 75 & 20 & 400 \\
\hline 12 & GBP & 52 & 72 & 20 & 400 \\
\hline 13 & $\mathrm{HZ}$ & 50 & 71 & 21 & 441 \\
\hline 14 & IPM & 60 & 75 & 15 & 225 \\
\hline 15 & IN & 50 & 72 & 22 & 484 \\
\hline 16 & IPS & 55 & 71 & 16 & 256 \\
\hline 17 & IA & 52 & 73 & 21 & 441 \\
\hline 18 & $\mathrm{KH}$ & 59 & 78 & 19 & 361 \\
\hline 19 & MW & 51 & 72 & 21 & 441 \\
\hline 20 & MA & 53 & 71 & 18 & 324 \\
\hline 21 & MDR & 49 & 70 & 21 & 441 \\
\hline 22 & NA & 58 & 74 & 16 & 256 \\
\hline 23 & NRM & 51 & 73 & 22 & 484 \\
\hline 24 & NI & 48 & 70 & 22 & 484 \\
\hline 25 & $\mathrm{PN}$ & 54 & 72 & 18 & 324 \\
\hline 26 & $\mathrm{RS}$ & 57 & 75 & 18 & 324 \\
\hline 27 & RSW & 50 & 70 & 20 & 400 \\
\hline 28 & $\mathrm{RN}$ & 55 & 71 & 16 & 256 \\
\hline 29 & SA & 51 & 72 & 21 & 441 \\
\hline 30 & SNA & 55 & 71 & 16 & 256 \\
\hline \multicolumn{2}{|c|}{ Total } & 1640 & 2204 & 564 & 10768 \\
\hline \multicolumn{2}{|c|}{ Average } & 54,67 & 73,47 & & \\
\hline
\end{tabular}

From the data above, it can be summed up that the different score of pretest and posttest is that the total score of pretest is 1640 and post-test is 2204 , then mean of pretest are 54.67 and post-test is 73.47 . There is 564 difference in total number and 18.8 in average, and it can be concluded that story completion technique can improve students' speaking ability.

\section{Reflection}

After implementing the story completion technique in narrative text and analyzing the students score in pretest and posttest, the writers evaluate some points: (1) Students' responds on story completion technique in narrative text were very positive. They were enthusiastic in completing the story and the technique can encourage 
students to speak although they do not have a lot of vocabulary. (2) Story completion technique in narrative text has given a significant impact in improving students speaking ability. (3) The writers (teacher) concur to conduct only one cycle due to the success of story completion technique implementation. Cycle I is successful in consequence of the good cooperation of students in applying the story completion technique and their enthusiasm to continue the story based on their imagination. Students are encouraged in creating the story so that their friends have to find and to create other sentences to complete the story. In this cycle, students speak more confidently due to the participation of all the member of the class.

\section{Discussion}

The result of the cycle I shows that students speak more effectively. They do not hesitate to deliver their ideas. Story completion technique has encouraged them to tell their imagination without thinking about grammar and pronunciation. This finding is in line with Wijaya et al. (2014), where they claims that story completion technique is effective in improving students' speaking ability and it can increase students' confidence in speaking. In line with Wijaya et al. (2014), Ashdaq (2017) also concur that story completion technique increases students' motivation and attention in learning English. Besides, it also encourage students to speak as long as they want.

It can be assumed that story completion technique is a good way to teach English especially speaking. This technique can make students to be more creative and confident to speak English because in this technique students are required to be able to continue stories that have been told by the teacher before. In addition, students are free to express the story according to their own imagination. Story completion can make the students explain the story. Moreover, the students also enjoy the learning process and the students were not bored during learning process.

Improvement of the students' speaking ability based on the story completion techniques learning activities showed a good progress. This technique makes the class situation more fun and alive. Students listen to their friend's story and then continue it. It also makes students more concentrate because they have to properly understand what their friends are saying, so that their story is relevant to what was previously told by their friends. 
Result of pretest and posttest also indicates that there is improvement on students' speaking ability. The gap score in preliminary test 1 and 2, where here is 564 difference in total number and 18.8 in average also shows that story completion technique is effective in improving students' speaking ability.

\section{CONCLUSION AND SUGGESTION}

\section{Conclusion}

The result of findings has shown that students' speaking ability has improved by using story completion technique. It can be proved from the students' score that become better in component of speaking that are accent, grammar, vocabulary, fluency and comprehension. Story completion technique can help the problem in learning process to make the students mastering English and keep practicing with easier and enjoyable. It has been proved from the result of preliminary test 1 and 2 , where the total score of preliminary test 1 is 1640 and preliminary test 2 is 2204 , then mean of preliminary test 1 are 54.67 and preliminary test 2 is 73.47 .

\section{Suggestion}

Story completion technique is recommended to be applied in the class, especially in English speaking. It oriented on the basic of a person when speaking, improving self-confidence and do not find it difficult because they do not directly give priority to grammar only focus on understanding but does not exclude other methods. However, in applying the story completion technique, the teacher must become a good instructor due to the unpredictable stories which will be appear from students during the lesson.

\section{REFERENCES}

Adler, S.Y., \& Oppenheim, D. (2015). Story Completion Play Narrative Methods for Preschool Children. Information Age Publishing. Retrieved from https://www.researchgate.net/publication/285329895_Story_completion_play_na rrative_methods_for_preschool_children

Ashdaq, M.R. (2017). The Use of Story Completion Technique to Improve Students' Speaking Ability of International Class Program Boarding Students of Teacher Training and Education. Faculty of State Institute for Islamic Studies Salatiga Batch 2015. Retrieved from http://e-repository.perpus.iainsalatiga.ac.id/2076/1/ 
Burns, A. (2009). Doing action research in English language teaching: A guide for practitioners. Retrieved from https://www.researchgate.net/publication/2880811

Hukom, S.J. (2019). Story Completion: a Technique in Teaching Speaking. Jurnal Tahuri 16(2): 1-9

Rifa'at, A.A. (2018). Stimulating You To Speak: A Strip Story as a Technique in Teaching Speaking. English and Literature Journal, 5 (1), 12-21

Safitri H., Rafli Z., \& Dewanti R. (2020). Improving students' speaking skill through task-based learning: An Action Research at the English Department. International Journal of Multicultural and Multireligious Understanding. Volume 7. Issue 6

Wijaya, W., Sukirlan, M., \& Sudirman. (2014). The Implementation of Story Completion Technique in Teaching Speaking. UNILA Journal of English Teaching, vol. 3 , no. 3 